\title{
The Five Seasons of Brasília
}

\section{Kenneth David Jackson}

Yale University, Estados Unidos

https://orcid.org/0000-0002-4269-7649

\section{ABSTRACT}

In João Almino's novel The Five Seasons of Love, the construction of prose accompanies the material construction of modernity. Characters must find and re-define themselves in a space of strangeness and estrangement. Their stories are allegories of transformation in a place without history.

KEYWORDS: Modernity; Catharsis; Allegory; Geometry; Metamorphosis.

\section{As cinco estações de Brasília}

\section{RESUMO}

No romance de João Almino, As cinco estações do amor, a construção da prosa acompanha a construção material da modernidade. Os personagens precisam redefinir-se e encontrar-se num espaço de estranhamento e alienação. As suas histórias são alegorias de transformação num espaço sem história.

PALAVRAS-CHAVE: Modernidade; Catarse; Alegoria; Geometria; Metamorfose. 
$\mathrm{T}^{\mathrm{T}}$ o write a novel about Brasília is to bring modernity into contemporaneity, for the futuristic capital city was the final grand project of national modernity, prepared by the earlier Ministry of Education and Health building in Rio de Janeiro (1937-45). The vast plains of the Brazilian interior were visited by the Louis Ferdinand Cruls commission in 1892 and the José Pessoa commission in 1955 to locate and demarcate land for the new capital. If in 1928, in Mário de Andrade's Macunaima, the eponymous modernist hero without any character traveled from the Amazon directly to São Paulo to marvel at its strange machines, on a return trip four decades later he could wander onto a new magical space of urban transformation as eerie as Amazonian spirits. How would Macunaíma retell his story after encountering Brasília in the middle of the road?

João Almino's novel, The Five Seasons of Love (As Cinco Estaçoes do Amor, 2001, English translation by Elizabeth Jackson, 2008), is the third of five novels set in Brazil's futuristic capital city, Brasília, inaugurated on April 21, 1960 on the high plains (15.79S, 47.88W) as a project of Oscar Niemeyer (1907-2012) and Lúcio Costa (1902-1998), Brazilian architects influenced by Le Corbusier (1887-1965) during his visits to Brazil from 1929-1936. In his novels, the construction of modernist prose accompanies the material construction of modernity. The opening of Brasília represented a culmination of Brazil's modernist and nationalist projects whose long-standing goals sought to open and unify the vast country, while promoting its individuality and modernity:

Brasília continues to surprise people visually and verbally [...] The monumental buildings appear as stand-alone objects, disconnected from a larger urban fabric. The entire space reads as one cohesive art object, due to the relative homogeneity of its design. This characteristic has earned the Plano Piloto the nickname 'open-air museum.' (BEAL, 2020, p. 43)

The construction of Brasília assured that the country's public and political image would continue to be closely associated with the artistic and social ideals of international modernism as expressed by its most prominent architects, artists, authors, and intellectuals. President Juscelino Kubitschek (1902-1976) used the slogan "50 years in 5" for the accelerated raising of the new capital.

The city was set down on a plain where nothing existed before, not even roads, as if delivered by spaceships. No one at that moment was from Brasília, nor was the construction complete when the city opened. With its north and south wings and central axis, the city was said to be in the shape of a cross, or an airplane, or a butterfly. The spatial and visual effect must have been both exhilarating and surreal when the Northeasterners who built the city walked out onto the white concave and convex structures of the new houses of Congress, along with Kubitschek. They were captured by Thomaz Farkas, Peter Scheier, Marcel Gautherot, Lucien Clergue and others in architecture-inspired photographs that after sixty years still project striking surrealistic and even anachronistic effects, marked by stark contrasts and vast landscapes that dwarf their human subjects (CLERGUE, 2013; ESPADA, 2010). Almino's novel explores the eerie fifth dimension of Brasília as the futuristic city of high modernism and the spell it casts over citizens who came from elsewhere in Brazil to occupy its vast spaces, at that moment outside of history. That fifth dimension is Brasília's mystery, part of a myth nurtured at the root of modernity itself, projecting pure form of the instantaneous moment without a past, buildings appearing on the 
high plain as if in a mirage, occupied by new citizens who moved there in a daze, carrying their impurities, personal histories, biographies, identity cards, and connections from the Brazilian world outside into an unfamiliar space. In Almino's narration, a change of seasons is a change of chapters and of ways of being as well. His narrative introduces a group of new residents and follows them into an unknown, experimental fifth season, which is the extra, futuristic season of Brasília with its unfamiliar shapes, spaces, and climate.

In the novel, new arrivals struggle to adjust and call Brasília the city of the "d's," dazzle, disappointment, despair, and divorce (ALMINO, 2008, p. 155). For newcomers, the city is a "free point in an empty space" (ALMINO, 2008, p. 9). The enigmatic protagonist of this novel is the city itself and its non-verbal vocabulary, which the people who move there must learn and understand like a new language and "a planalto way of being" (ALMINO, 2008, p. 9). Almino's overarching theme is the encounter of a resplendent city on the high plain, standing outside of history and popular culture, with newly arrived citizens who may find it all obscure, uncharted, inexplicable. Its extra fifth season is an ineffable and enigmatic presence, like a spaceship dropped to pick up its aliens.

Author Clarice Lispector (1920-1977) captured the strangeness and estrangement of Brasília in a creative essay written in 1962, speaking of the city's "frightening beauty" (LISPECTOR, 2002 , p. 516). Her description is a catalog of the city's alienation:

When I died, one day I opened my eyes and there was Brasília. I was alone in the world. There was a taxi standing there, without a driver. What a scare. Lúcio Costa and Oscar Niemeyer, two solitary men. I see Brasília as I see Rome. Brasília began with a simplification of ruins. The ivy has not yet grown. Apart from the wind there is something else that blows. It is only recognized by the supernatural tension of the lake. Wherever a child stands it may fall, and fall out of the world. Brasília is on the edge. If I lived here I would let my hair grow down to the ground. Brasília had a splendid past that no longer exists. That kind of civilization disappeared thousands of years ago. (LISPECTOR, 2002, p. 636)

The city is as artificial as the world must have been when it was created. It is a never-never world with no way in, no way out, an open-air prison. Here in the lucidity of dreams the soul casts no shadow on the ground. The city is a motionless profile of insomnia, the ruin of a splendorous past that no longer exists; its inhabitants are desperate fugitives. It is construction with space for clouds, silent, cold. Here there can be no crimes of love. Chance is abrupt, the city is haunted, it has no gender, no one can breathe deeply here, passion dies, grandiosity is useless, space and time are the same. One of Clarice's phrases can be taken as the frame of Almino's five seasons of love: "when I discover what frightens me, then I will know what I love here" (LISPECTOR, 2002 , p. 637). Fear takes his characters to the edge, and some do not return. Almino takes their snapshots in prose, yet when the photos are developed only the city's landmarks appear, as Clarice predicts. In the new lives the characters construct for themselves, the only open space of their potential new existence is the line of the horizon. The characters who stay in Brasília live in suspended animation, waiting for something extraordinary to happen to break the spell.

Almino's novel is constructed as a spiritual exercise in the form of an allegory. Reminiscent of Gil Vicente's Auto da Alma (1518), his characters are lost on the path of life and must be rescued with the help of a guardian angel and their own free will: 
SOUL: Guardian angel, oer me still, keep thy ward that am so frail and of the earth, on all sides thy watch fulfil, that nothing kill my true wealth nor e'er prevail o'er its high worth. Ever encompass me and shield, for this conflict with great fear fills all my sense, noble protector in this field, lest I should yield, let thy gleaming sword be near for my defence. Still uphold me and sustain for I fear lest I may stumble, fail and fall.

ANGEL: Power uncontrolled is thine, and an independent will unbound by fate: even so in His might divine did God design that thou in glory mightst fulfil thy heavenly state. He gave thee understanding pure, imparted to thee memory, free will is thine, that so thou mayest e'er endure with purpose sure, knowing that He has fashioned thee to be divine. (VICENTE, 2009, pp, 3-4)

Finding themselves lost in a futuristic city, many characters pass through a contemporary dark night of the soul before finding their way in the mystery of Brasilia, and some are lost. The female narrator has a double name; she is Ana, when introverted and self-contained, Diana when extroverted in pure desire. The personal metamorphosis of Ana/Diana reflects the recasting of urban form and space demanded by the new city. Arriving in Brasília from Taimbé, a small town in Minas Gerais, Ana/Diana is emptying out and reconstructing her life by forgetting or expelling everything. She avoids going out and confines herself to "the mountain of books, letters, and other papers accumulated throughout my life" (ALMINO, 2008, p. 35), before deciding to face a blank page to write her story. Hers will be a hypertext that continually constructs itself, a counter point for actual life, an evasion worthy of the open city. By deciding to write without memory, in her apartment-cocoon, Ana/Diana sets in motion a metamorphosis, based on the Greek myth of the Phoenix, which will begin her rebirth and transformation into a butterfly in the shape of Brasília.

She is a retired philosophy professor, living alone with her housekeeper Berenice, nieces Juliana and Regina from Taimbé, a dog and two cats. Her Brasília story is still undefined and incomplete: "Here I am looking at blank pages on the desk. They expect an enormity of me: uncontained words, like red brushstrokes. Like blood" (ALMINO, 2008, p. 31). Her new life in Brasília will be a book only about the present, with no boundaries between past and future; she calls it a "spiritual house" where she will be reborn, where she can forget everything, without history, freely and spontaneously, erasing and condensing her existence into a present moment. Ana examines and begins to throw out, one by one, and at times with regret, documents and letters from her ex-husband Eduardo. To rid herself even of memories of him, she separates and destroys the papers in his folder, discarding words in the expectation that new ones will appear: "To become naked and light, free myself of the papers, be reborn free of the weight of the past, is all that I want" (ALMINO, 2008, p. 36). When her practical housekeeper Berenice objects to her throwing out all the papers in forty-five cardboard boxes, she dumps them into a large pile on the floor.

Ana/Diana spends her time with a close circle of friends who call themselves "The Useless," all but two of whom will leave the city, and they meet for long inconclusive discussions every Thursday in the Beirute Bar: Chicão, Japona, Joana, Helena, Eva, Maria Antônia, Noberto, Cadu. Their stories are a panorama of urban Brazil under the weight both of estranged modernity and the military dictatorship that ruled Brazil from 1964-1985, limiting the scope 
of their conversations and imagination through the restrictions of oppression and confinement, incongruous in the open spaces of a futuristic metropolis. Maria Antônia moves to São Paulo to join the landless movement. Joana eventually moves to Rio de Janeiro, marries and joins the high bourgeoisie, while Helena abandons her documents, leaves to join the guerilla struggle against the regime, and never returns. Ana admires Noberto, who plays the guitar and sings, and is amused and surprised on her return from San Francisco having transitioned to Berta, and later Mona Habib. The "Useless" go underground when the military police come looking for Helena, only to regroup for a final reunion on December 31, 1999 to celebrate the turn of the millennium. Together again, they represent for Ana the unfulfilled past:

Tonight, I feel the surviving Useless are all still friends. In each of us there is complicity from the old days. We have changed physically and spiritually. But we still trust each other, not because of other common interests of similar ideas. Because we lived through some crises together and together we lost some of the same things. We dreamed the same unfulfilled dreams [...] as if we were frozen in time, seeing each other not with today's eyes but rather with eyes of thirty years ago. (ALMINO, 2008, p. 121)

The story of the Useless is presented as a bildungsroman, a generation condemned to repeat the past, without lessons to learn from their futuristic and seemingly timeless city. Outside the Beirute Bar where they meet, they are incapable of practicing "a planalto way of reverse being." Chicão describes their predicament as "living in the splendor of chaos" (ALMINO, 2008, p. 72).

Ana narrates her developing personal conception of life as spiritual exercises, with which she attempts to come to terms with the city. At the Brasília University, for example, she participates in a debate of "isms" that she calls a circus. As Diana, she composes a discourse about the acceleration of time and the instant in motion, accepting the possibility of unforeseen and unknown realities:

Everything can evolve in many directions, even those that we don't foresee, and unknown reality is always greater than the dreams we dream. I disagree with whoever says that there is nothing new under the sun and whoever thinks that things aren't done like in the old days. With someone who believes that nothing changes and someone else who, on the contrary, thinks that everything that happens is without precedent. (ALMINO, 2008, p. 71)

In the instant, like the sudden appearance of Brasília, she foresees a place for ideals that can revolutionize tradition. She conceives of the instant as "[...] a sack in which I place several images, concepts, and reflections, even though I know that it escapes and flees from me like a mirage, as I approach it" (ALMINO, 2008, p. 71). It is a place where she can evaluate dreams, plans, and ideas in a suspended moment, outside of time.

Modernist narration absorbs influential concepts of time and perception from the turn of the century. The concept of the instant as a fixed point containing all past and future, as perception, is described by American philosopher and psychologist William James:

Crudely and popularly we divide the course of time into past, present, and future; but, strictly speaking, there is no present; it is composed of past and future divided by an indivisible point or instant. That instant, or time point, is the strict present. If we take this as the present time point, it is 
clear that the minimum of feeling contains two portions - a sub-feeling that goes and a sub-feeling that comes. One is remembered, the other imagined. The limits of both are indefinite at beginning and end of the minimum, and ready to melt into other minima, proceeding from other stimuli. (JAMES, 1950, I, p. 607)

Likewise, for French philosopher Henri Bergson, in "the state of my duration [...] in that continuity of becoming which is reality itself, the present moment is constituted by the quasiinstantaneous section effected by our perception in the flowing mass [where] the actuality of our present lies" (BERGSON, 1911, p. 178). What Bergson called pure memory was likewise "detached from time."

In modernist literature, Diana's concept of the expandable instant, or moment, brings to mind, and perhaps revisits, Virginia Woolf's "moments of being," thought to be constantly changing yet abstract spaces of potentiality and epiphany, as Jeanne Schulkind explains:

That self was an elusive will o' the wisp, always just ahead on the horizon, flickering and insubstantial, yet enduring. She believed the individual identity to be always in flux, every moment changing its shape in response to the forces surrounding it: forces which were invisible emerge, others sink silently below the surface, and the past on which the identity of the present moment rests, is never static, never fixed like a fly in amber, but as subject to alteration as the consciousness that recalls it. (SCHULKIND, 1985, p. 12)

Reflecting the rejection of the past and invention of potential futures seen in the historical avant-gardes, Ana's instantaneism is a point of potentiality, encompassing Woolf's combination of past self and present self in moments of intuition and transcendence, when new identities are created in flashes that open consciousness of the moment in all its plurality. At the same time, Ana's instant is one of reevaluation and self-doubt, since she eliminates memory and the past by burning all her papers. The only way forward for her, like the Phoenix, is to rise from her own ashes. No one at the Brasília University responds or understands her, and her inflamed philosophical presentation as Diana about solidarity and ethics ["No reality is immutable, all ideas can be reborn, men can aspire to better ways of life (ALMINO, 2008, p. 72)] is out of place among purely technical discussions. What humanistic philosophy could match the city's pure geometrical forms?

Fear sets in motion Ana/Diana's metamorphosis through a process of destruction and purgation that pushes her over an abyss. Early on, she puts bars on the window and two crossbars on the door. Fearful of urban violence, she purchases a pistol, "thirty-eight caliber, the so-called big three eight" (ALMINO, 2008, p. 21), which becomes a catalyst of self-negation. When she is home alone and some armed kids try to break in, Diana takes control and fires all five bullets in a moment of "courage and insanity" (ALMINO, 2008, p. 44), after which she hears a verbal threat. When Berta is murdered in a hate crime, the stolen gun used turns out to be hers, and when she is attacked on the street by one of the attackers seeking revenge, the gun also turns out to be the same. Unwilling to accept a mediocre or unresolved existence, Ana seeks revenge and sets a personal revolution in motion. In a state of depression, she sets fire to her immense pile of papers and seeks to eradicate the world in an apocalypse: "If there were a bomb here, I 
would blow up the house, Brasília, the world, this work by an ill-tempered God" (ALMINO, 2008, p. 131). She uses the same pistol for the last time in a suicide attempt. However, the bullet lodges behind her ear, and on regaining consciousness in the hospital she receives outpourings of support from the Useless, university colleagues, and above all from her supportive neighbor Carlos, who grows roses after his wife Carmen's death.

The fifth chapter or season dramatizes Ana's attempted suicide, catharsis, and resurrection, recounting the difficult maturation of a character through the stages of immolation, exile, and return. Ana/Diana's Brasília story turns to allegory, in a drama both personal and universal. Her metamorphosis recapitulates Strauss's tone poem, Tod und Verklärung, while adding an unexpected fifth movement to the composition. The path to a curative restoration requires exile from Brasília, and Ana flees to her place of origin. She returns to Taimbé and the care of her relatives. In the interior, Ana is aware of the Brasília she left behind: "Brasília is the heavy streaks of rain on the window, the noisy cars passing, the loneliness of a big city, death, unrequited love, anguish" (ALMINO, 2008, p. 139), and in Taimbé she recovers the telluric feelings that remind her of an historically authentic self. Yet again, the double motivation of fear and loneliness intercedes. After two weeks, Ana becomes restless and knows she must return to the capital. Although not immediately reciprocating his feelings, she decides to accept Carlos's proposal and "jumps off the springboard" (ALMINO, 2008, p. 144) toward Brasília of her own free will. Her reemergence from Taimbé to Brasília resonates with Woolf's description of how two very different sides of a room come together to form an intense moment of being:

Which should I describe first - the living half of the room or the sleeping half? [...] But I was thinking; feeling; living; those two lives that the two halves symbolized with the intensity, the muffled intensity, which a butterfly or moth feels when with its sticky tremulous legs and antennae it pushes out of the chrysalis and emerges and sits quivering beside the broken case for a moment; its wings still creased; its eyes dazzled, incapable of flight. (WOOLF, 1985, pp. 123-124)

Ana's near-death experience and survival find parallels in Woolf's description of her recuperation from the death of her half-sister Stella Duckworth as metamorphosis: "I remember saying to myself after she died: 'But this is impossible; things aren't, can't be, like this' -the blow, the second blow of death struck on me; tremulous, filmy eyed as I was, with my wings still creased, sitting there on the edge of my broken chrysalis" (WOOLF, 1985, p. 124).

The chrysalis as a metaphor of transformation or metamorphosis can be found throughout modernist literature, especially in cases of female initiation and authority. In Woolf's first novel, The Voyage Out (1915), for example, the semi-autobiographical character Rachel Vinrace wishes to break out of the pattern that her Victorian culture imposes upon women (FROULA, 1986, pp. 63-90). Use of the chrysalis in modernist literature ranges from topics such as coming of age, class and interracial struggles, displacement and exile to formation of the self (OLIVA, 2011). Nabokov wrote about butterflies as a lepidopterist and their special capacity for mimicry that could be applied to fiction: "The mysteries of mimicry had a special attraction for me [...] I discovered in nature the nonutilitarian delights that I sought in art" (NABOKOV, 1948). Metamorphosis becomes an iconic technique of literary modernism after Kafka's short story Die Verwandlung 
(1915), in which salesman Gregor Samsa awakens one morning to find himself changed into a "monstrous vermin." In Woolf's Orlando (1928), the main character, an English nobleman, changes sex, as does Noberto/Berta in Almino's novel. According to Franco Moretti, supernatural metamorphosis as a literary technique, as in Macunaíma, "seems to lie at the meeting point between rites of passage, mythic narratives and the Bildungsroman" (MORETTI, 2000, p. 246).

In Taimbé Ana has had time to reflect and to emend her philosophy of the instant from a new perspective:

So, I revise my theory of instantaneism. Things evolve in many directions, but there are moments in which the whole of them presents itself harmoniously from an unexpected perspective. Sometimes, looking in a new direction, we discover that the confusion settles. There are too many things in the world, and it's always possible to find a way to assemble them into a given shape. (ALMINO, 2008, p. 144)

Emerging from the chrysalis after attempted suicide, Ana/Diana has begun to accept the radically unfamiliar sculpture of Brasília, which seen through the angle of her experience is still "woven of illusions, memories, and imagined lives," not yet separated from a past way of being. Through her metamorphosis, coming out the other side of self-doubt and self-destruction, Ana/ Diana begins to see Brasília afresh in its singular modernity as an affirmation of potentiality from a moment of being that takes in all angles:

Well then, before I used to be indecisive and thought that only questioning was worthwhile. I wanted to undo everything. Now I refuse to think that everything is nothing. I'm no longer concerned that it's better to live by questions and indecision, to predict that everything in unpredictable, to determine that everything is indeterminate. On the contrary, everything can be affirmed in the eternity of an instant, when I recompose the whole in a specific way. Everything, the whole. One must analyze the instant from the angle that contains all angles at the same time, in order to discern its clear crystalline form. (ALMINO, 2008, pp. 144-145)

In the fire her papers burned, however, they left traces in their ashes. On returning to the incinerated house with Carlos, Ana recognizes their "carbonized emotions," which symbolize a stage of rebirth. She reevaluates her idea of the instant, which in place of fragments and unconnected instants now permits her to envision a new entity as a whole, replete with possibilities, a clear crystalline form that on her return resembles Brasília. It contains a vision of the future, bringing to mind the one in the crystalline globe Thetys shows to Vasco da Gama on the Isle of Love in The Lusiads. Ana chooses to accept unexpected perspectives and the radically different appearance of things, which when seen from multiple angles marshal a new will to gather and embrace each fragment or instant, discovering meanings hidden in the city's inert forms. Ana's miraculous restoration and return from suicide leads to her own "Garden of Salvation," or Isle of Love, whereas her transformed way of being results from a decision forged from painful experience, a willful act.

If through acceptance of her life Ana reflects changes similar to those of the character Laura, who comes of age in Clarice's novel Near to the Wild Heart, written before the construction of Brasília, Ana's intellectual and personal quest is to come to terms as an adult with a futuristic 
capital without history, "papers," or discourse. Almino's novel questions whether the city can be historicized, turned into a large plantation resembling Brazil's familiar pattern of land ownership since colonial times, or whether to live in Brasília its citizens must undergo a catharsis that will convey them to a fifth season or perception. Ana's final "state of grace" after her return from near suicide and exile belongs only to this new frontier: "I see the immense sky before me, there on the other side of the lake, above the ministry buildings, where an enormous red sun blinds me [...] drunk on the excess of light that projects a shadow of dreams" (ALMINO, 2008, p. 156). Visible signs of the changes of seasons in nature are the leitmotif that sustains an underlying cycle of rebirth. Ana/Diana's apotheosis continues to be visible symbolically throughout the seasons in the flowering quaresmas of Autumn and the green insects crawling across the fronds of a fern, perhaps in the first stage of yet another metamorphosis. The futuristic city surprisingly changes with nature while Ana/Diana observes it.

In Almino's novel, the city is the stage for characters from elsewhere who must adjust and create new lives according to the "planalto way of being":

I take the Grand Axis. Ahead of me, the neon quadrilateral at the National Shopping Center is lit. The red in the ads seems to continue into the sky. Across the crimson horizon the clouds trace spiral figures in smoke. Right in the middle, an enormous gray question mark. In the middle of the sky and my life. (ALMINO, 2008, p. 6)

Social and human relationships, professions and politics, topics of concern and conversation must be redefined at a personal cost by the city's shape and substance. Noberto-Berta and Helena are lost to prejudice and to armed resistance, respectively, whereas Ana/Diana barely survives the fire that consumes her past and the bullet that lodges in her head. All of the Useless foresee the need to reinvent themselves, led by the retired philosopher Ana/Diana: "Before I can formulate a sentence, Japona answers for me: 'And it is, it is a different world, only it's completely different from what we imagined"' (ALMINO, 2008, p. 114).

The Useless agree to meet on December 31, 1999 to face the new millennium: "To the new millennium! - cries Maria Antônia” (ALMINO, 2008, p. 115). Chicão gives the group a spontaneous lecture on the origin of zero: "A number inspired by emptiness and the desert. Very appropriate for Brasília - Maria Antônia says" (ALMINO, 2008, p. 116). The moment arrives, accompanied by bottles of champagne to mark a much-awaited definitive and irreversible transformation: "It's midnight, the start of the New Year, the New Century, the New Millennium" (ALMINO, 2008, p. 117).

The moment is both a severe judgment of modernity and an allegorical quest for salvation from the alienating and imposing futuristic city by referencing history and time. The gathering of the Useless echoes the rituals of the "Garden of Salvation," a bizarre cult as strange as the idea of the city itself. There, the prophetess Iris Quelemém, a name derived from a character in Guimarães Rosa's novel Grande Sertão: Veredas, represents the fusion of Brasília as pure modern form with Brazil's rich tradition of religious mediums and messianic movements in the Northeast (BEAL, $2020,85)$. In the small green insect crawling across the fronds of a fern, Ana as prophetess sees a small and perhaps illusory sign of hope for survival. Brasília is the allegorical stage where the 
Devil can intervene (ALMINO, 2008, p. 125) to derail characters lost in the grand scale of the pilot plan who seek mundane salvation in a new humanism. Will they prove capable of instilling hope and bringing metamorphosis to the butterfly design of the futuristic city, or will Brasília be the stone in the middle of the road that deters Macunaíma on his return to the Amazon?

\section{REFERENCES}

ALMINO, João. The Five Seasons of Love. Elizabeth A. Jackson, trans. Austin: Host Publications, 2008.

ANDRADE, Mário de. Macunaíma. São Paulo: E. Cupolo, 1928; edição crítica. Telê Porto Ancona Lopez, ed. Rio de Janeiro: Livros Técnicos e Científicos Editora; Secretaria da Cultura, Ciência e Tecnologia, 1978.

BEAL, Sophia. The Art of Brasília, 2000-2019. New York: Palgrave Macmillan, 2020.

BERGSON, Henri. Matter and Memory. Translated by Nancy Margaret Paul and W. Scott Palmer. London: George Allen and Unwin, 1911.

CLERGUE, Lucien. Brasília. Osfilder: Hatje Cantz Verlag, 2013.

ESPADA, Heliosa, org. As construções de Brasília. São Paulo: Instituto Moreira Salles, 2010.

FROULA, Christine. Out of the Chrysalis: Female Initiation and Female Authority in Virginia Woolf's The Voyage Out. Tulsa Studies in Women's Literature. Vol. 5, No. 1 (Spring 1986), pp. 63-90.

JAMES, William. Principles of Psychology. Vol. 1. New York: Dover, 1950; New York: H. Holt, 1890.

LISPECTOR, Clarice. Brasília. In: Brasil 1920-1950, Da Antropofagia à Brasília. Jorge Schwartz, org. São Paulo: MAB-FAAP Museu de Arte Brasileira; Cosac \& Naify, 2002, pp. 515-516, 636-637.

LISPECTOR, Clarice. Near to the Wild Heart. Alison Entrekin, trans. New York: New Directions, 2012.

MORETTI, Franco. The Way of the World. London: Verso, 2000.

NABOKOV, Vladimir. On Butterflies: Life as a Lepidopterist. The New Yorker (June 5, 1948).

OLIVA, Juan Ignacio. The Painful Chrysalis: Essays on Contemporary Culture and Literary Identity. Berlin: Peter Lang, 2011.

ROSA, João Guimarães. Grande Sertão: Veredas. Rio de Janeiro: J. Olympio, 1956.

SCHULKIND, Jeanne. Introduction. In: Virginia Woolf. Moments of Being. Orlando: Harcourt, Brace \& Co., 1985

WOOLF, Virginia. Moments of Being. Edited and with an introduction and notes by Jeanne Schulkind. Orlando: Harcourt, Brace \& Col, 1985.

VICENTE, Gil. Four Plays of Gil Vicente. Aubrey F. G. Bell, trans. March 24, 2009. http://www.pgdp.net 